\title{
Global Trade, Admiralty Law And Zero Sum Games
}

Bohdan Pikas, Niagara University, USA

Anastasia Pikas, Niagara University, USA

\begin{abstract}
A shipment of heavy sand from Australia was contaminated by sea water during a hurricane. Upon examination of the ship's hold hatches, it was determined by the consignee that the hold hatches were in poor repair and faulty. Immediate compensation for the insurance deductible and shipping expense was demanded of the ship's owners. Claiming an act of God under Admiralty Law, the ship's owner refused payment. Upon consultation with maritime attorneys, the consignee decided to apply a provision of maritime law and "arrest" the ship to force payment.
\end{abstract}

Key words: Admiralty Law, Maritime law, Arbitration, Lloyd's, Subrogate, Global trade, Zero sum games, Supply Chain, Shipping, Beaufort scale, Damaged cargo, Ship arrest

\section{INTRODUCTION}

n June of 2007 an ocean freighter of Indian registry left a port in Australia loaded with 3000 tons of zircon destined for the Lauren Ceramics Company in New York. Off loading of the zircon was to take place at Welland, Ontario in Canada. En route, the ship made a port call in New Orleans U.S.A. When the ship left New Orleans and exited the Gulf of Mexico around the Florida Keys, the freighter ran into Hurricane Dean which was raging in the Atlantic Ocean off of the coast of Florida. The captain of the ship was aware of the weather conditions, but most ships try to put to sea during a storm as they can ride out the weather conditions better at sea than moored at the dock. The chance of dock damage to the ship would have also caused a delay in other product delivery and the daily cost of this delay was significant. The hurricane measured 8-9 on the Beaufort Scale, which was not particularly severe but nevertheless, waves breaking over the freighter caused seawater to penetrate the hatch covers and leak into the holds. Sailing through the hurricane and to the mouth of the St. Lawrence Seaway, the ship made landfall at Welland, Ontario where the Lauren Ceramics Company was about to receive over a million dollars of salt water contaminated zircon

\section{THE SHIP}

Ship size was a serious consideration for cargo shipments through the St.Lawrence Seaway. Ship classifications are made based on the waterways they can navigate. A Panamax size ship is the largest possible that can travel to through the Panama Canal. Others are a Seawaymax (through the St. Lawrence Seaway), a Suezmax (through the Suez Canal), Capesize (around the two world capes) and the Vlcc/Ulcc, very large crude carrier, ultra large crude carrier. The VLCC and UlCC are often too large and draft too much to be brought into world ports and must be off loaded off shore.

The ship carrying Lauren Ceramics' cargo was a Seawaymax ship. The maximum size of a Seawaymax ship cannot exceed 740' in length, 78' in beam and cannot draft more than 26'. This size is determined by the size of the locks and water depth on the Seaway. Generally, by today's standards, this is a small ship. About the only smaller ocean going ship would be a tramp steamer servicing short routes.

Lauren Ceramics had no control on the quality of the ship and was at the mercy of the ship's owners as to maintenance and repair of the vessel. Often, these ships are not well maintained and have seen a long service life. A cargo ship has about a 30 year life span before the salt water environment causes irreparable damage to it. Smaller shipping companies make no money in maintaining a ship and have been known to postpone or avoid maintenance in order to 
increase bottom line profits. A piece of capital equipment earns nothing when it is in dry dock for service and maintenance.

\section{THE COMPANY AND PRODUCT}

The company, Lauren Ceramics is based in New York State and produces ceramic powders from heavy purified sands. These sands, upon processing, become zircon, rutile, and nord. Lauren Ceramics contracts for the purchase of these raw materials from various mining companies in Africa and Australia. The foreign companies refine raw sands that bear the zircon, rutile, and nord and market them globally. The process is to centrifuge raw material repeatedly until the desired heavy sands remain.

During the processing, most if not all foreign matter is removed and the remaining product is specified as pure according to one of three different international specification standards, these being the British, South African, and Russian Standards.

Lauren Ceramics places the responsibility of purchasing, determining terms of sale, shipment, storage, and negotiation of contractual non-compliance with its Director of Purchasing, Melvin Woodland. Melvin's job is to ensure that transoceanic shipments arrive with enough raw material so that production is on going and at the same time minimal inventories are kept. This task is particularly difficult in that there are no guaranteed schedules that can be predicted for ocean freight. Ships have sunk because of storms and even today, sea piracy does occur. Currently, piracy is particularly prevalent off the coast of Somalia located on the Horn of Africa, in the Malacca Straits off the coast of Indonesia and off the coast of Nigeria. Lauren Ceramics' shipment orders never fill all the holds of an ocean transport and the company has no way of knowing if the ship will be in pirate infested waters picking up other cargo. Therefore, Lauren's cargo could very well be in jeopardy if the ship sails into the pirate hot spots of the world further exacerbating the raw material delivery problem. Also, the crews of these ships are often from third world countries and they are paid only a few dollars a day. A cargo worth several million dollars is a large temptation and crews have been known to sail to other ports, sell the cargo and either scuttled the ship or sell it for scrap in some lesser developed country.

Global and international companies attempting to emulate the Japanese model of JIT (just in time ) to reduce the carrying costs of inventory are at the mercy of the aforementioned hazards and in today's climate of high level competition from other global suppliers, a loss of inventory would be devastating. It would be particularly devastating to Lauren Ceramics as the company is a provider/vendor of ceramic powders to the manufacturers of many consumer and industrial products such as bathtubs, commodes and computer chips. Manufacturers of these products are giants in the industry (American Standard, Kohler, Intel) and a disruption of their component materials would not be taken lightly. Lauren Ceramics is not a large company and timely delivery of product and a high level of service is its hallmark. Lauren Ceramics does insure its cargo with the world premier maritime insurer, Lloyd's of London. A loss would only compensate the lost investment. The loss to reputation, service and lost customers is not insurable. Any disruption of inventory flow could be catastrophic to Lauren Ceramics as they are not a large player in the supply chain.

Melvin's purchase procedure is to evaluate future production needs from production reports, charter a vessel through an independent charter company in London and then to arrange the actual dates of delivery of the raw material. A firm contract is placed with the raw material supplier, the vessel arrives at the supplier's port of call and the product is loaded FOB aboard ship. At this time an insurance policy is taken out through Lloyd's of London for the value of the shipment less a $\$ 50,000$ deductible. The value of the product varies from fifteen cents to twenty-five cents a pound. This particular shipment of 3000 tons of zircon was at twenty cents a pound or $\$ 1,200,000$. The cost of the shipping was $\$ 150,000$.

When the zircon arrives at the Welland, Ontario warehousing site, (located on the Welland Canal which joins lakes Ontario and Erie thereby by passing Niagara Falls) it is off loaded into a weather proof warehouse. The ship's owners allocate 48 hours for the off loading. After the 48 hour period, a break down in Lauren's equipment or other delays in off loading are charged at $\$ 10,000$ per day, the approximate daily operating cost of the ship. Delays are not taken lightly as other companies in the Great Lakes ports are expecting arrival of their products on a timely basis. (Lauren's 3000 tons generally occupies only one hold out of a 5 or 6 hold freighter.) When the zircon or other sands are 
safely warehoused, the ship sails on through the Welland Canal and on to other ports.

Then Lauren Co. has daily production requirements trucked from Welland, Ontario to their manufacturing facility in N.Y. Upon arrival, the sands are melted in a $5000^{\circ} \mathrm{f}$ arc furnace and the resulting product is ground into different types of ceramic powders. These powders are sold to companies that produce everything from high tech silicon chips to residential bath tubs.

\section{THE ARRIVAL}

When the freighter arrived with Lauren's shipment of zircon at their Welland facility a series of procedures took place. Melvin, the Director of Purchasing was on hand with his video camera. The purpose of the video camera was to document visually the condition of the ship, the ship's hold and the opening of the hold. Also the condition of the product was video taped. There have been instances where the product was contaminated with rust and scale from a poorly maintained ship. Along with Melvin was Don Anderson, a ship surveyor. Don's job was to verify the condition of the ship and to estimate the weight of the cargo. Lauren's cargo is weighed two different ways. At the point of origin, the selling company loads the cargo on a conveyor system. The conveyor system has a scale built into it called a weight armature. As the cargo traverses the conveyor belt the armature automatically calculates weight per section of conveyor belt and speed of the belt. Speed times weight per section results in an accurate measurement of total cargo weight.

In Welland, Ontario no such system exists as it is cost prohibitive. This is where Don Anderson, ship surveyor earns his money. His weighing method is to weigh the ship by measuring its loaded draft and comparing it to the unload draft. His plus or minus degree of accuracy is one inch of draft. Don can achieve an accuracy figure of 50 tons, plus or minus, on a 3000 ton cargo. This may seem to be a large error factor but in actuality it is acceptable to Lauren Ceramics Company. Melvin's contracts have a one percent weight fudge factor built into them.

When the ship's hold was opened and the first clam bucket of zircon was lifted, water poured out of the sides of the bucket. All stevedoring was stopped and Melvin and Don descended into the hold. The zircon was badly contaminated with seawater, which would, when dried out, leave an unacceptable residue of salt in the product. Don, in assessing the situation, determined that the hold's hatch cover was in a poor state of repair and was incapable of keeping out seawater. Melvin discussed this situation with the ship's captain who maintained that the hatch was in good working condition and the fault lay with Hurricane Dean. The ship's captain said that because of the hurricane this problem was an "act of God" which no man could prevent and that his company was in no way liable for the contamination. Furthermore, the captain insisted that the cargo be removed or financial penalties would be imposed because of delay. Melvin, having no immediate recourse, proceeded to off load the cargo into a separate area of the warehouse so that seawater run off would not contaminate other sands already in the warehouse.

\section{THE PROBLEMS}

After the ship left for Lake Erie, Melvin was faced with a series of problems. First was how to get more zircon so that production wouldn't cease. Second was what to do with 3000 tons of contaminated zircon. Third was how to get the shipping company to accept responsibility for the contaminated cargo.

The problem of restocking sufficient zircon was broached to the original supplier in Australia. He indicated that they had a ship loaded with zircon due to arrive at New Orleans on December 20th. They indicated that they could release 1400 tons to Lauren Ceramics and that it could be barged up the Mississippi River for further shipment east to Lauren Ceramics. Working rapidly to locate a warehouse in the Ohio system to rent space, Melvin discovered that there was not one warehouse available. Business activity was so strong in the U.S. that all the warehouses were at $125 \%$ of capacity. Barge storage was out of the question because the material would have to be trucked at about 40 tons per truck and the expense would be prohibitive.

Another alternative to restocking was to purchase 1400 tons (this quantity being needed until a new shipment could arrive) from domestic sources. The purchase price would be about double the original cost of the product. Shipment would be less expensive because the material could be transported by rail to the Welland facility. If restocking 
from the Australian company was not possible in a timely manner, then 3000 tons would ultimately have to be purchased from domestic sources. It was unknown at this time if domestic sources could provide that amount of zircon on such short notice. Whatever the situation, Melvin knew that he had to get enough zircon to keep production on schedule. The only alternative was to shut down production and notify Lauren's customers that Lauren would not be able to fulfill their orders. In today's competitive environment, this alternative was unacceptable.

The second problem was what to do with 3000 tons of salt contaminated zircon. Melvin knew of a company that could build a dike around the material and, with an expensive procedure, flush the sodium out of the zircon. The cost of this would be equivalent to purchasing domestic zircon stocks and would take about a month to do. Melvin did not think that existing inventory could keep production going long enough for this to happen.

The other alternative was to sell the contaminated zircon on the open market for about 50 cents on the dollar. The problem with this was that it would soften the market price for zircon for the original producer. The original producer's customers may not know that this was contaminated material being sold and may insist that the zircon producer's price be less because they knew material was available cheaper. Lauren's goodwill with the producer would be damaged.

The third problem of how to make Lauren whole, and place financial and legal responsibility where it belonged was particularly vexing. The insurer of the cargo, Lloyd's of London, would indemnify Lauren Ceramics for their loss but there would still be the problem of the $\$ 50,000$ deductible self insurance and the $\$ 150,000$ shipping cost. On this point, Melvin had strong feelings that the shipping company had the responsibility and not Lloyd's. Needing a sounding board Melvin called Don Anderson, the ship's surveyor and expressed his thoughts. Don said that if it was up to him he would seize the ship and hold it until a Letter of Undertaking (guaranteeing payment for the cargo) was issued by the Indian shipping company.

\section{THE SEIZURE}

Melvin was intrigued with the thought of seizing the ship. He decided to explore this possibility further but needed to find out where the ship was and where it was going. He quickly discovered that the ship was in Duluth loading corn and this gave him some time to start seizure procedures. In his research he found out that although there was much trade talk about seizure of a ship, no one had ever done it. He then called agents in New York City that register hundreds of ships and was told that, yes, under Admiralty Law, this was possible. He was informed that he should get a magistrate and a sheriff and seize the ship. At the same time Melvin contacted a maritime lawyer versed in both Canadian and American Admiralty law and was given the go ahead to begin seizure procedures.

Two questions rapidly arose; firstly which jurisdiction is the ship to be seized in? The Great Lakes and the St. Lawrence Seaway meander between Canada and the U.S. in almost a random pattern. The ship couldn't be seized on the high seas because no country has jurisdiction. Secondly what do you do with the ship once you seize it? This was not a twenty foot pleasure craft but a six hundred foot ocean freighter.

Nevertheless, Melvin was determined that he was going to initiate seizure proceedings and notified the ships owners that this would happen if they did not produce a Letter of Undertaking. The ships owners indicated that their ship was not at fault for the contamination and that if the seizure was not done correctly they would sue Lauren Ceramics for false arrest. Although Lloyd's of London would indemnify Lauren Ceramics for the cargo loss, Lauren would still be out the $\$ 50,000$ deductible and the $\$ 150,000$ shipping cost.

During the discussion with the ship's owners and consultation with maritime legal experts, Melvin was tracking the ship's progress through the Great Lakes system. To his surprise, he discovered that the ship was sailing extraordinarily quickly, in particular, when the ship negotiated the Welland Canal on its return voyage, normally a minimum of twelve hours sailing time, Melvin learned that the ship made the voyage in just under eight hours and was in Lake Ontario. Melvin quickly determined that the ship was running for the open Atlantic. If the ship reached the Atlantic Ocean then all of Melvin's negotiating capabilities would be gone. 
Melvin decided that he would have the ship "arrested" in the Canadian port of Montreal. To that end he had a proper Canadian legal arrest warrant executed and contacted the Canadian Constabulary in preparation of seizure activities. Also, he notified the Indian ship owners of his preparations and intentions. They, in turn, restated that they were not at fault and the seawater contamination due to Hurricane Dean was an "Act of God" which held them harmless of any subsequent damage.

During Melvin's research he discovered that both Canadian and U.S. courts measured Hurricane force on a Beaufort Scale. This scale rated Hurricane Dean at a Beaufort 8-9 and marine case law assigned "Acts of God" damage to a Beaufort 12 value. This information was provided to the ship's owners and it was reiterated that the ship would be "arrested" in Montreal unless a Letter of Undertaking for the deductible and shipping costs was forth coming and the situation sent to binding arbitration.

The Indian owners, fearing that the ship would in fact be "arrested" in Montreal and knowing full well that that port froze solid during the latter part of December and stayed frozen until March, relented. Given that their ship would not be a profit making venture for four months because of the frozen port and that the operating cost was $\$ 10,000$ per day, they agree to fax a Letter of Undertaking to Lauren's bank and submit to binding arbitration.

\section{LLOYD'S OF LONDON'S POSITION}

It is almost a certainty that Lloyd's would subrogate the payment to Lauren Ceramics to the shipping company and their insurer. Should the ship's owners and/or insurance refuse to recompense Lloyd's for their payment, Lloyd's maritime solicitors would then have to apply Admiralty Law in a yet to be determined judicial district. The question of which countries' court and which portions of Admiralty law will apply rests with Lloyd's maritime solicitors. The present choices are, preferably in London where the original charter company has offices (they would certainly be served a lawsuit), London would be a "friendly" court. The least preferred option would be in India, the shipping company's base of operations.

It is not clear at this time as to what "court of jurisdiction" clause was in Lauren Ceramics' contract nor is it clear if it would be applicable for Lloyd's suit.

Many nations under the original colonization by England have developed legal systems base on English common law and historic Admiralty Law provisions. India has an Admiralty Law in place. If the case is heard in British courts, Lloyd's solicitors are well versed in the applicable maritime law. If it's heard in India, then it would be preferable to hire Indian expert maritime law solicitors. This would provide a local expert in Indian Admiralty Law and a friendly face to the court. It is possible to circumvent an extended, expensive lawsuit in India by going to the Indian Council of Arbitration. The Council hears commercial cases, including maritime matters and renders decisions. The Council is a signatory to various international agreements and has a cooperation agreement with the London Court of International Arbitration. (http://www.ficci.com/icanet/new-ruls/maritimearbitration.pdf) Of course, the option of last resort would be to apply the relevant country's Admiralty Law. This is a swamp of ancient, historic and current statutes, rules, and regulations which Lloyd's may not wish to tackle.

Lloyd's is in a true cost benefit analysis position. Their total payout was $\$ 1,150,000$. This number could represent a drop in the bucket if a court case is initiated. It may be in the best interested for Lloyd's to go the arbitration route, either with the London Court of International Arbitration or with the Indian Council of Arbitration, should the Indian shipping company agree. If a court lawsuit is pursued, it could result in an interesting zero sum game.

\section{AUTHOR INFORMATION}

Prof. Bohdan Pikas has been teaching and researching in marketing at Niagara University N.Y. His specialty is Distribution and International Marketing. His research interests are in applied global marketing and strategy.

Adjunct Professor Anastasia Pikas has been teaching and researching in Finance, Statistics and Market Research for several decades at Niagara University N.Y. Her specialty is corporate financial analysis and application of statistics to market research. 
NOTES 